\title{
REVIEW
}

\section{Clinical review: use of venous oxygen saturations as a goal - a yet unfinished puzzle}

\author{
Paul van Beest' ${ }^{1 *}$, Götz Wietasch', Thomas Scheeren', Peter Spronk ${ }^{2,3,4}$ and Michaël Kuiper ${ }^{3,4,5}$
}

\begin{abstract}
Shock is defined as global tissue hypoxia secondary to an imbalance between systemic oxygen delivery and oxygen demand. Venous oxygen saturations represent this relationship between oxygen delivery and oxygen demand and can therefore be used as an additional parameter to detect an impaired cardiorespiratory reserve. Before appropriate use of venous oxygen saturations, however, one should be aware of the physiology. Although venous oxygen saturation has been the subject of research for many years, increasing interest arose especially in the past decade for its use as a therapeutic goal in critically ill patients and during the perioperative period. Also, there has been debate on differences between mixed and central venous oxygen saturation and their interchangeability. Both mixed and central venous oxygen saturation are clinically useful but both variables should be used with insightful knowledge and caution. In general, low values warn the clinician about cardiocirculatory or metabolic impairment and should urge further diagnostics and appropriate action, whereas normal or high values do not rule out persistent tissue hypoxia. The use of venous oxygen saturations seems especially useful in the early phase of disease or injury. Whether venous oxygen saturations should be measured continuously remains unclear. Especially, continuous measurement of central venous oxygen saturation as part of the treatment protocol has been shown a valuable strategy in the emergency department and in cardiac surgery. In clinical practice, venous oxygen saturations should always be used in combination with vital signs and other relevant endpoints.
\end{abstract}

*Correspondence: p.van.beest@anest.umcg.n

'Department of Anaesthesiology, University Medical Center Groningen, University of Groningen, Hanzeplein 1, Groningen 9700 RB, the Netherlands

Full list of author information is available at the end of the article

\section{Introduction}

Shock is defined as global tissue hypoxia secondary to an imbalance between systemic oxygen delivery $\left(\mathrm{DO}_{2}\right)$ and systemic oxygen demand $\left(\mathrm{VO}_{2}\right)$. Unrecognised and untreated global tissue hypoxia increases morbidity and mortality. Accurate detection of global tissue hypoxia is therefore of vital importance. Physical findings, vital signs, measuring central venous pressure and urinary output are important but insufficient for accurate detection of global tissue hypoxia [1-3]. Measurement of mixed venous oxygen saturation $\left(\mathrm{SvO}_{2}\right)$ from the pulmonary artery has been advocated as an indirect index of tissue oxygenation [4]. As a result of an extensive debate in the literature [5-7], however, use of the pulmonary artery catheter has become somewhat unpopular. In contrast, insertion of a central venous catheter in the superior vena cava via the jugular of the subclavian vein is considered standard care in critically ill patients. Just like $\mathrm{SvO}_{2}$, the measurement of central venous oxygen saturation $\left(\mathrm{ScvO}_{2}\right)$ has been advocated in order to detect global tissue hypoxia.

Venous oxygen saturations have been the subject of research for over 50 years, but especially over the past decade the amount of literature describing changes in $\mathrm{ScvO}_{2}$ and $\mathrm{SvO}_{2}$ in critically ill patients, including high-risk surgical patients, increased substantially. This led to high expectations with respect to the use of venous oxygen saturation as a therapeutic goal. The aim of the present review is to summarise the evidence and to discuss the clinical utility of both $\mathrm{SvO}_{2}$ and $\mathrm{ScvO}_{2}$ in the treatment of critically ill patients, including high-risk surgical patients.

We performed a search of the PUBMED database from 1980 to 2010 using combinations of the following terms: $\mathrm{SvO}_{2}, \mathrm{ScvO}_{2}$, venous oxygen saturation, venous saturation, critically ill, shock, septic shock, high risk surgery, surgery, operation. The articles published in English were included when published in a peer-reviewed journal. The clinical investigations had to concern adults. Additionally, bibliographies of relevant articles were also screened.

\section{Physiology}

Understanding the physiology of venous saturations is essential for effective application in critically ill patients and during the perioperative period. 


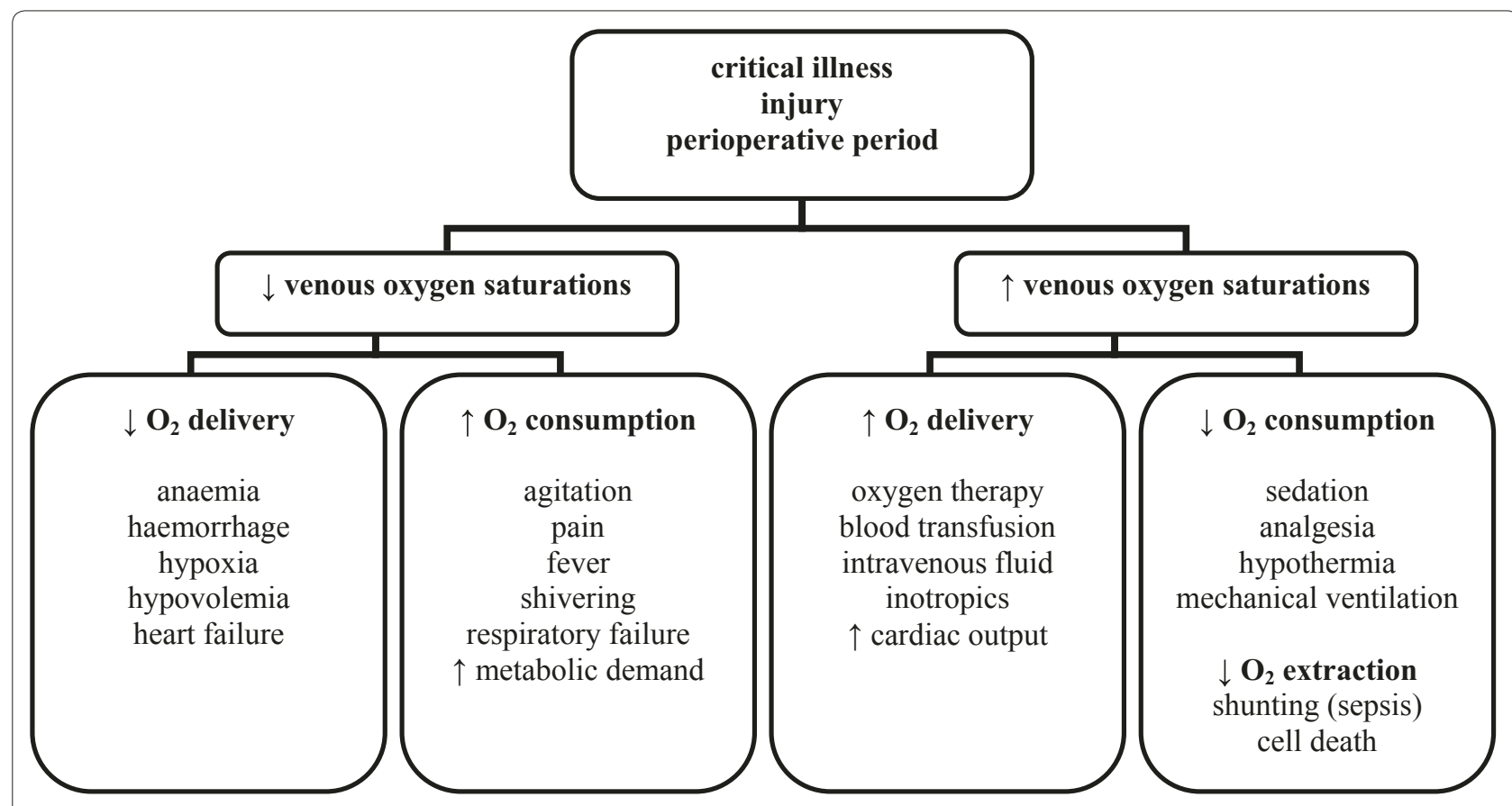

Figure 1. Multiple physiologic, pathologic and therapeutic factors may influence the value of central venous oxygen saturation.

$\mathrm{SvO}_{2}$ depends on arterial oxygen saturation $\left(\mathrm{SaO}_{2}\right)$, the balance between $\mathrm{VO}_{2}$ and cardiac output $(\mathrm{CO})$, and haemoglobin $(\mathrm{Hb})$ levels. According to the Fick principle [8], $\mathrm{SvO}_{2}$ can be described by the following formula:

$$
\mathrm{SvO}_{2}=\left[\mathrm{SaO}_{2}-\mathrm{VO}_{2} / \mathrm{CO}\right][1 / \mathrm{Hb} \times 1.34]
$$

Increased $\mathrm{VO}_{2}$ will be compensated by increased $\mathrm{CO}$. If this is not adequate - that is, if oxygen demand is not met - elevated oxygen extraction occurs in the peripheral tissues and consequently $\mathrm{SvO}_{2}$ will drop. $\mathrm{SvO}_{2}$ thus reflects the balance between oxygen delivery and oxygen demand [9]. The normal range for $\mathrm{SvO}_{2}$ is 65 to $75 \%[4,10]$. Low $\mathrm{SvO}_{2}$ is predictive of bad outcome [4,11], whereas normal or supranormal $\mathrm{SvO}_{2}\left(\right.$ or $\left.\mathrm{ScvO}_{2}\right)$ values do not guarantee adequate tissue oxygenation $[12,13]$. If tissue is not capable of extracting oxygen (for example, in the case of shunting and cell death), venous return may have a high oxygen content despite persistent cellular hypoxia.

A variety of physiological and pathological changes may influence venous saturation (Figure 1) and thus require different therapeutic interventions. Recognition of the aetiology of any derangement is obligatory for the safe use of venous saturation as a therapeutic goal.

\section{Central versus mixed venous oxygen saturation}

In general there has been considerable debate on equality or interchangeability of $\mathrm{ScvO}_{2}$ and $\mathrm{SvO}_{2}$ [14-16] (see Table 1). In critically ill patients, substituting $\mathrm{SvO}_{2}$ by $\mathrm{ScvO}_{2}$ results in large variability [16-21]. This could in part be explained by modifications of blood flow distribution and oxygen extraction by brain and splanchnic tissue. In this situation, $\mathrm{ScvO}_{2}$ may provide the false impression of adequate body perfusion. Also, whether a positive $\mathrm{ScvO}_{2}-\mathrm{SvO}_{2}$ gradient can be used as a marker of greater oxygen utilisation and a predictor of survival remains a subject of debate [20,22,23].

In contrast, other studies have stated that $\mathrm{ScvO}_{2}$ could indeed be used as a substitute for $\mathrm{SvO}_{2}$ [24-26]. For example, Reinhart and colleagues performed continuous measurements of venous oxygen saturations in anaesthetised dogs over a wide range of haemodynamic conditions, including hypoxia, haemorrhage and resuscitation, and described close tracking between $\mathrm{ScvO}_{2}$ and $\mathrm{SvO}_{2}$ [24]. However, correlation was lowest during hypoxia, one of the areas of greatest clinical interest. Nevertheless, precise determination of absolute values for $\mathrm{SvO}_{2}$ from $\mathrm{ScvO}_{2}$ was not possible, as was seen before [21,27-29].

Additionally, the relationship between $\mathrm{CO}$ or the cardiac index and venous saturations has been evaluated in critically ill patients. So far, the results have been inconclusive for both $\mathrm{SvO}_{2}$ and $\mathrm{ScvO}_{2}$. Larger trials are needed before clinical recommendations can be made regarding their clinical use [19,30-33].

\section{Clinical use of venous oxygen saturations Cardiac failure}

Venous oxygen saturations have been shown to have diagnostic, prognostic, and therapeutic qualities in critically ill patients with acute myocardial infarction (see 
Table 1. Studies comparing mixed venous oxygen saturation and central venous oxygen saturation

\begin{tabular}{|c|c|c|c|}
\hline Study & Design and subjects & Results & Conclusions \\
\hline \multirow[t]{2}{*}{$\begin{array}{l}\text { Varpula and } \\
\text { colleagues [14] }\end{array}$} & \multirow[t]{2}{*}{$\begin{array}{l}n=16 ; \text { septic shock; ICU; } \\
72 \text { paired samples }\end{array}$} & $\begin{array}{l}\text { Mean } \mathrm{SvO}_{2} \text { below mean } \mathrm{ScrO}_{2} \text { at all time points; } \\
\text { bias of difference } 4.2 \%\end{array}$ & \multirow[t]{2}{*}{$\begin{array}{l}\text { Difference between } \mathrm{ScvO}_{2} \text { and } \mathrm{SvO}_{2} \text { varied highly; } \\
\mathrm{SvO}_{2} \text { cannot be estimated on basis of } \mathrm{ScvO}_{2}\end{array}$} \\
\hline & & $\begin{array}{l}95 \% \text { limits of agreement }-8.1 \text { to } 16.5 \% \text {; difference } \\
\text { correlated with } \mathrm{Cl} \text { and } \mathrm{DO}_{2}\end{array}$ & \\
\hline $\begin{array}{l}\text { Martin and } \\
\text { colleagues [16] }\end{array}$ & $\begin{array}{l}n=7 ; 580 \text { comparative } \\
\text { measurements; critically } \\
\text { ill patients; ICU; with and } \\
\text { without interventions }\end{array}$ & $\begin{array}{l}\text { Difference } \geq 5 \% \text { in } 49 \% \text { during periods of stability } \\
\text { and in } 50 \% \text { during periods with therapeutic } \\
\text { interventions }\end{array}$ & $\mathrm{ScvO}_{2}$ monitoring not reliable \\
\hline $\begin{array}{l}\text { Chawla and } \\
\text { colleagues [17] }\end{array}$ & $\begin{array}{l}n=32 \text { postsurgical and } \\
n=21 \text { medical; ICU }\end{array}$ & $\begin{array}{l}\mathrm{SvO}_{2} \text { consistently lower than } \mathrm{ScvO}_{2} \text { with mean } \\
( \pm \mathrm{SD}) \text { bias }-5.2 \pm 5.1 \%\end{array}$ & $\begin{array}{l}\mathrm{SvO}_{2} \text { and } \mathrm{ScvO}_{2} \text { not equivalent; substitution of } \\
\mathrm{ScvO}_{2} \text { for } \mathrm{SvO}_{2} \text { in calculation of } \mathrm{VO}_{2} \text { resulted in } \\
\text { unacceptably large errors }\end{array}$ \\
\hline \multirow{2}{*}{$\begin{array}{l}\text { Kopterides and } \\
\text { colleagues [18] }\end{array}$} & \multirow[t]{2}{*}{$n=37 ;$ septic shock } & Mean $\mathrm{SvO}_{2}$ below mean $\mathrm{ScvO}_{2} ;$ mean bias $-8.5 \%$ & \multirow{2}{*}{$\begin{array}{l}\mathrm{ScvO}_{2} \text { and } \mathrm{SvO}_{2} \text { not equivalent in } \mathrm{ICU} \text { patients } \\
\text { with septic shock; substitution of } \mathrm{ScvO}_{2} \text { for } \mathrm{SvO}_{2} \text { in } \\
\text { calculation of } \mathrm{VO}_{2} \text { resulted in unacceptably large } \\
\text { errors }\end{array}$} \\
\hline & & $\begin{array}{l}95 \% \text { limits of agreement }-20.2 \text { to } 3.3 \% \text {; this } \\
\text { resulted in higher } \mathrm{VO}_{2} \text { values }\end{array}$ & \\
\hline $\begin{array}{l}\text { Ho and colleagues } \\
{[19]}\end{array}$ & $\begin{array}{l}n=20 \text {; cardiogenic or septic } \\
\text { shock }\end{array}$ & $\begin{array}{l}\mathrm{ScvO}_{2} \text { overestimated } \mathrm{SvO}_{2} \text { with mean bias } 6.9 \% \text {; } \\
95 \% \text { limits of agreement }-5.0 \text { to } 18.8 \% \text {; changes of } \\
\mathrm{ScvO}_{2} \text { and } \mathrm{SvO}_{2} \text { did not follow the line of perfect } \\
\text { agreement }\end{array}$ & $\begin{array}{l}\mathrm{ScvO}_{2} \text { and } \mathrm{SvO}_{2} \text { are not interchangeable } \\
\text { numerically }\end{array}$ \\
\hline \multirow[t]{4}{*}{$\begin{array}{l}\text { van Beest and } \\
\text { colleagues [20] }\end{array}$} & \multirow[t]{4}{*}{$\begin{array}{l}n=53 ; 265 \text { paired samples; } \\
\text { sepsis; ICU; multicentre }\end{array}$} & $\begin{array}{l}\text { Mean } \mathrm{SvO}_{2} \text { below mean } \mathrm{ScvO}_{2} \text { at all time points; } \\
\text { bias of difference } 1.7 \%\end{array}$ & $\begin{array}{l}\mathrm{ScvO}_{2} \text { does not reliably predict } \mathrm{SvO}_{2} \text { in patients } \\
\text { with sepsis }\end{array}$ \\
\hline & & \multirow{2}{*}{$\begin{array}{l}95 \% \text { limits of agreement }-12.1 \text { to } 15.5 \% \text {; identical } \\
\text { results for change in } \mathrm{ScvO}_{2} \text { and } \mathrm{SvO}_{2}\end{array}$} & Trend of $\mathrm{ScvO}_{2}$ not superior in this context \\
\hline & & & \multirow{2}{*}{$\begin{array}{l}\mathrm{ScvO}_{2}-\mathrm{SvO}_{2} \geq 0 \text { not associated with improved } \\
\text { outcome }\end{array}$} \\
\hline & & $\begin{array}{l}\text { Distribution of }\left(\mathrm{ScVO}_{2}-\mathrm{SvO}_{2}\right)(<0 \mathrm{vs} . \geq 0) \text { similar in } \\
\text { survivors and nonsurvivors }\end{array}$ & \\
\hline \multirow{3}{*}{$\begin{array}{l}\text { Scheinmann and } \\
\text { colleagues [21] }\end{array}$} & \multirow{3}{*}{$\begin{array}{l}n=24 \text {; critically ill cardiac } \\
\text { patients; CCU }\end{array}$} & \multirow{3}{*}{$\begin{array}{l}\mathrm{ScvO}_{2} \text { levels in superior vena cava are greater } \\
\left.\text { than } \mathrm{SvO}_{2} \text { in shock ( } 58 \pm 13 \mathrm{vs} .47 .5 \pm 15 ; r=0.55\right) ; \\
\text { changes in } \mathrm{ScvO}_{2} \text { reflect changes in } \mathrm{SvO}_{2} \\
(r=0.90) ; \mathrm{ScvO}_{2} \text { from right atrium is similar to } \mathrm{SvO}_{2} \\
(49.2 \pm 19 \mathrm{vs} .49 .2 \pm 19 ; r=0.96)\end{array}$} & $\mathrm{SvO}_{2}$ consistently lower than $\mathrm{ScvO}_{2}$ \\
\hline & & & Poor correlation in heart failure or shock \\
\hline & & & Changes in $\mathrm{ScvO}_{2}$ reflect changes in $\mathrm{SvO}_{2}$ \\
\hline \multirow[t]{2}{*}{$\begin{array}{l}\text { Dueck and } \\
\text { colleagues [25] }\end{array}$} & \multirow[t]{2}{*}{$\begin{array}{l}n=70 ; 502 \text { comparative sets; } \\
\text { neurosurgery }\end{array}$} & $\begin{array}{l}95 \% \text { limits of agreement ranged from } 6.8 \% \text { to } \\
9.3 \% \text { for single values }\end{array}$ & \multirow{2}{*}{$\begin{array}{l}\text { Numerical } \mathrm{ScvO}_{2} \text { values not equivalent to } \mathrm{SvO}_{2} \text { in } \\
\text { varying haemodynamic conditions; trend of } \mathrm{ScvO}_{2} \\
\text { may be substituted for the trend of } \mathrm{SvO}_{2}\end{array}$} \\
\hline & & $\begin{array}{l}\text { Correlations between changes of } \mathrm{SvO}_{2} \text { and } \mathrm{ScvO}_{2} \text { : } \\
r=0.755, P<0.001\end{array}$ & \\
\hline \multirow{3}{*}{$\begin{array}{l}\text { Reinhart and } \\
\text { colleagues [26] }\end{array}$} & \multirow{3}{*}{$\begin{array}{l}n=32 \text {; critically ill patients; } \\
\text { ICU; continuous parallel } \\
\text { measurements }\end{array}$} & $\mathrm{ScvO}_{2}$ closely paralleled $\mathrm{SvO}_{2^{\prime}}$ in vitro $r=0.88$ and & \multirow{3}{*}{$\begin{array}{l}\text { Continuous fibreoptic measurement of } \mathrm{ScvO}_{2} \\
\text { Potentially reliable tool to rapidly warn of acute } \\
\text { change in the oxygen supply/demand ratio }\end{array}$} \\
\hline & & Scro & \\
\hline & & $\begin{array}{l}\text { ScvO } \\
\text { changed more than } 5 \%\end{array}$ & \\
\hline $\begin{array}{l}\text { Ladakis and } \\
\text { colleagues [28] }\end{array}$ & $\begin{array}{l}n=31 \text { surgical and } n=30 \\
\text { medical; critically ill patients; } \\
\text { ICU }\end{array}$ & $\begin{array}{l}\text { Significant difference between mean } \mathrm{ScvO}_{2} \text { and } \\
\mathrm{SvO}_{2}(69.4 \pm 1.1 \text { vs. } 68.6 \pm 1.2 \%) ; r=0.945 \text { for total } \\
\text { population }\end{array}$ & $\begin{array}{l}\mathrm{ScvO}_{2} \text { and } \mathrm{SvO}_{2} \text { are closely related and } \\
\text { interchangeable for initial evaluation }\end{array}$ \\
\hline $\begin{array}{l}\text { Tahvanainen and } \\
\text { colleagues [29] }\end{array}$ & $\begin{array}{l}n=42 \text {; critically ill patients; } \\
\mathrm{ICU} ; \mathrm{ScvO}_{2} \text { as representative } \\
\text { of real changes in pulmonary } \\
\text { shunt }\end{array}$ & $\begin{array}{l}\text { Significant correlation between measured } \\
\text { variables between } P A \text { blood samples and both } \\
\text { superior vena cava and right atrial blood samples } \\
(P<0.001)\end{array}$ & $\begin{array}{l}\mathrm{ScvO}_{2} \text { can replace } \mathrm{SvO}_{2} \text {; exact } \mathrm{SvO}_{2} \text { value can only } \\
\text { be measured from the PA itself }\end{array}$ \\
\hline
\end{tabular}

$\mathrm{CCU}$, cardiac care unit; $\mathrm{Cl}$, cardiac index; $\mathrm{DO}_{2^{\prime}}$ oxygen delivery; $\mathrm{PA}$, pulmonary artery; $\mathrm{ScvO}_{2^{\prime}}$ central venous oxygen saturation; $\mathrm{SvO}_{2^{\prime}}$, mixed venous oxygen saturation; $\mathrm{VO}_{2}$, oxygen consumption.

Table 2). $\mathrm{SvO}_{2}$ was particularly reduced in patients with cardiogenic shock or left ventricular failure. Patients with cardiac failure are unable to increase $\mathrm{CO}$ during periods of increased oxygen need. Changes in oxygen demand will therefore only be compensated by changes in oxygen extraction in the same direction and indicated by inverse changes in venous oxygen saturations. Consequently, a drop in venous oxygen saturations will be a marker of 
Table 2. Studies describing central venous oxygen saturation in clinical settings

\begin{tabular}{ll}
\hline Study & Design and subjects \\
\hline $\begin{array}{l}\text { Rady and } \\
\text { colleagues [1] }\end{array}$ & $n=36$; critically ill patients; ED \\
$\begin{array}{l}\text { Pope and } \\
\text { colleagues [13] }\end{array}$ & $\begin{array}{l}n=619 \text { registries treated with } \\
\text { EGDT; observational study }\end{array}$ \\
$\begin{array}{l}\text { Ander and } \\
\text { colleagues [35] }\end{array}$ & $\begin{array}{l}\text { Controls } n=17, \text { high lactate } \\
\text { group } n=22, \text { low lactate group } \\
n=5 ; \text { chronic congestive heart } \\
\text { failure; ED }\end{array}$
\end{tabular}
$\begin{array}{ll}\text { Scalea and } & n=26, \text { trauma patients with } \\ \text { colleagues [40] } & \text { suggested blood loss }\end{array}$

Di Filippo and $\quad n=121$ brain injury after colleagues [41] trauma; noncontrolled study

Pearse and $\quad n=118$, major surgery colleagues [65]

Rivers and colleagues [73]

Trzeciak and colleagues [74]

Kortgen and colleagues [75]

Jones and colleagues [76]

Micek and colleagues [78]

Shapiro and colleagues [80]

Jones and colleagues [94] $n=263 ;$ RCT; EGDT vs. controls; severe sepsis, septic shock; ED

$n=16$ pre-EGDT; $n=22 \mathrm{EGDT}$

$n=30$ controls $n=30$ septic shock

Implementation procedure: septic shock

$n=79$ pre-intervention; $n=77$ post-intervention; ED

$n=60$ before implementation order set; $n=60$ after implementation order set; ED

$n=51$ historical controls; $n=79$ septic shock

Multicentre, randomised; $n=$ 300 severe sepsis, septic shock

Goals: lactate clearance vs. $\mathrm{ScvO}_{2}$

\section{Results}

Additional therapy is needed after haemodynamic stabilisation to normal blood pressure and heart rate

Groups: $\mathrm{ScvO}_{2}<70 \%, \mathrm{ScvO}_{2} 71$ to $89 \%, \mathrm{ScvO}_{2}>90 \%$

Multivariate analysis: initial high $\mathrm{ScvO}_{2}$ higher mortality

$\mathrm{ScvO}_{2}$ lower in high lactate group than in low lactate group $(32 \pm 12 \%$ vs. $51 \pm 13 \%)$ and control $(60 \pm 6 \%)$; after treatment

There was a significant decrease of lactate and increase in $\mathrm{ScVO}_{2}$ in the high lactate group compared with the low lactate group

Despite stable vital signs, 39\% of the patients had $\mathrm{SCVO}_{2}<65 \%$; these patients required more transfusions; linear regression analysis demonstrated superiority of $\mathrm{ScVO}_{2}$ to predict blood loss compared with normally allowed parameters

Nonsurvivors showed higher lactate, lower $\mathrm{ScvO}_{2}$ values; patients with $\mathrm{ScvO}_{2} \leq 65 \%$ showed higher 28 day mortality, ICU LOS and hospital LOS than patients with $\mathrm{ScvO}_{2}>65 \%$

After multivariate analysis, lowest $\mathrm{Cl}$ and lowest $\mathrm{ScvO}_{2}$ were associated with postoperative complications; optimal $\mathrm{ScvO}_{2}$ cut-off value for morbidity prediction was 64.4\%; in the first hour after surgery, significant reductions in $\mathrm{ScvO}_{2}$ were observed, without significant changes in $\mathrm{Cl}$ or oxygen delivery index

EGDT (goal: $\mathrm{ScvO}_{2} \geq 70 \%$ ) showed better survival (absolute 16\%), lower lactate; more fluids, red cell transfusion and inotropics

Less PAC utilisation; more fluids and dobutamine used; similar costs

Implementation: use of dobutamine, insulin, hydrocortisone and activated protein C increased

Amount of fluids and packed blood cells unaffected Mortality significantly lower after implementation (27\% vs. $53 \% ; P<0.05$ ).

Controls: more renal failure at baseline

Greater crystalloid volume and vasopressor infusion Mortality 18 vs. $27 \%$

More appropriate antimicrobial regimen

More fluids, more vasopressors

Less vasopressor by time of transfer to the ICU

Patients received more fluids, earlier antibiotics, more vasopressors, tighter glucose control, more frequent assessment of adrenal function, not more packed blood cells

Higher in hospital mortality $\mathrm{ScvO}_{2}$; nonsignificant difference (predefined $-10 \%$ threshold)

\section{Conclusions}

$\mathrm{ScvO}_{2}$ can be utilised to guide therapy in this phase

Also high $\mathrm{ScvO}_{2}$ values predictive for mortality

Once patients with decompensated endstage congestive heart failure are identified, these patients require aggressive alternative management

$\mathrm{SCvO}_{2}$ is a reliable and sensitive method for detecting blood loss; it is a useful tool in the evaluation of acutely injured patients

$\mathrm{ScvO}_{2}<65 \%$ in first 24 hours after admission in patients with major trauma and head injury is associated with prolonged hospitalisation and higher mortality

Results suggest that oxygen consumption is also an important determinant of $\mathrm{SCvO}_{2}$. reductions in $\mathrm{ScvO}_{2}$ are independently associated with postoperative complications

EGDT provides benefits to outcome

EGDT endpoint can reliably be achieved Implementation of sepsis bundle feasible Survival benefit

Implementation resulted in mortality reduction

Shorter hospital LOS

Lower 28-day mortality

Implementation sepsis protocol feasible

No survival benefit

No significantly different in-hospital mortality between normalisation of lactate clearance compared with normalisation $\mathrm{ScvO}_{2}$

$\mathrm{Cl}$, cardiac index; ED, emergency department; EDGT, early goal-directed therapy; LOS, length of stay; PAC, pulmonary artery catheter; RCT, randomised controlled trial; $\mathrm{SCvO}_{2}$, central venous oxygen saturation. 
cardiac deterioration. Patients with low venous oxygen saturations in the early disease stage may be considered in shock $[34,35]$. Also, patients with sepsis and known decreased left ventricular function seem to benefit from early goal-directed therapy (EGDT) when treated for sepsis [36] according to the Surviving Sepsis Campaign guidelines [37]. Finally, in the setting of cardiopulmonary resuscitation, a $\mathrm{ScvO}_{2}$ of $72 \%$ is highly predictive for return of spontaneous circulation [38].

\section{Trauma}

In the initial assessment of trauma patients, an adequate judgement of possible blood loss is essential. Compared with conventional parameters, venous oxygen saturations are superior in predicting blood loss [39,40]. Moreover, after major trauma with brain injury, $\mathrm{ScvO}_{2}$ values below $65 \%$ in the first 24 hours are associated with higher mortality (28-day mortality $31.3 \%$ vs. $13.5 \%$ ) and prolonged hospitalisation (45 days vs. 33 days) [41].

\section{High-risk surgery}

In cardiac surgery patients, $\mathrm{SvO}_{2}$ has been shown to be superior to the mean arterial pressure and heart rate as a qualitative warning sign of substantial haemodynamic deterioration. However, results on the predictive value of $\mathrm{SvO}_{2}$ for $\mathrm{CO}$ in clinical settings are inconsistent [42-44]. Nevertheless, continuous $\mathrm{SvO}_{2}$ monitoring enables the early diagnosis of occult bleeding or could show poor tolerance of a moderate anaemia due to the inability of the patient with chronic heart dysfunction or preoperative negative inotropic treatment (for example, $\beta$ blockers) to increase $\mathrm{CO}$ in the face of anaemia. Furthermore, temporary decreases of $\mathrm{SvO}_{2}$ values after cardiac surgery are of prognostic value and may predict the development of arrhythmias [45-47]. Also, probably due to an increased oxygen extraction ratio, decreased $\mathrm{SvO}_{2}$ values during weaning from mechanical ventilation are predictive for extubation failure [48-50]. Finally, good predictive values of $\mathrm{SvO}_{2}$ for mortality have been described [51,52]. This suggests beneficial effects of $\mathrm{SvO}_{2}$ monitoring, at least during and after cardiac surgery.

Goal-directed therapy has been shown to improve outcome after major general surgery [53]. Originally, the goals in the protocol group were supranormal haemodynamic and oxygen transport values (cardiac index $>4.5 \mathrm{l} /$ minute $/ \mathrm{m}^{2}, \quad \mathrm{DO}_{2}>600 \mathrm{ml} / \mathrm{minute} / \mathrm{m}^{2}, \quad \mathrm{VO}_{2}$ $>170 \mathrm{ml} /$ minute $/ \mathrm{m}^{2}$ ). In this group a significant reduction of complications, hospital stay, duration of mechanical ventilation and mortality was achieved when the pulmonary artery catheter was placed preoperatively [54]. Such a strict predefined concept holds certain risks, however, and should not be translated to all patients [55-57]. Metaanalyses of haemodynamic optimisation in high-risk patients revealed haemodynamic optimisation to be beneficial only when interventions were commenced before development of organ failure [58,59]. Several of the studies described showed improved outcome, possibly including long-term survival, when goal-directed therapy was commenced before surgery [54,60-62]. Perhaps owing to methodological shortcomings, a multicentre trial that randomised surgical patients to pulmonary artery catheter guided or conventional management failed to show a difference in outcome [63,64]. More recently a reduction in postoperative complications and duration of hospital stay was described when goaldirected therapy was used postoperatively [65-67]. However, the abovementioned findings do not provide definite answers on how to use venous saturations as a therapeutic goal. Only one interventional trial used $\mathrm{ScvO}_{2}$ as a therapeutic goal in perioperative care [68]. In this study the intervention group received therapy to achieve an estimated oxygen extraction ratio $<27 \%$ after predefined goals for arterial pressure, urine output, and central venous pressure had been achieved. Fewer patients developed organ failure in the $\mathrm{ScvO}_{2}$ group [68].

\section{Sepsis and septic shock}

In a large multicentre study, three different cohorts of a very heterogeneous population of critically ill patients were compared for survival after different strategies for haemodynamic therapy had been applied: control versus supranormal values for the cardiac index $\left(>4.5 \mathrm{l} / \mathrm{minute} / \mathrm{m}^{2}\right)$ or normal values for mixed venous saturation. In total, the anticipated goal was only achieved in one-third of the patients. There was no significant reduction in morbidity or mortality in any group [69]. An important reason for this may be the late timing of the intervention (that is, after occurrence of organ failure), implying that all patients suffered severe damage and received significant treatment before inclusion.

Global tissue hypoxia as a result of systemic inflammatory response or circulatory failure is an important indicator of shock preceding multiple organ dysfunction syndrome. The development of multiple organ dysfunction syndrome predicts the outcome of the septic patient [37]. Treatment strategies aimed at restoring the balance between $\mathrm{DO}_{2}$ and $\mathrm{VO}_{2}$ by maximising $\mathrm{DO}_{2}$ have not been successful $[57,69,70]$.

In line with studies over several decades $[1,21,27$, $35,40,71$ ] and based on recommendations [72], Rivers and colleagues randomised 263 patients with severe sepsis or septic shock to standard therapy or EGDT. Compared with the conventionally treated group, the $\mathrm{ScvO}_{2}$ guided group received more fluids, more frequently dobutamine, and more blood transfusion during the first 6 hours. This resulted in an absolute reduction in 28-day mortality of $16 \%$ [73]. 
A large number of studies that implemented certain treatment protocols in the emergency department including antibiotic therapy and tight glucose control, for example [74-79] - showed a significant decrease in mortality. EGDT endpoints (central venous pressure 8 to $12 \mathrm{mmHg}$, mean arterial pressure $\geq 65 \mathrm{mmHg}$, and $\mathrm{ScvO}_{2}$ $270 \%$ ) can well be achieved in an emergency department setting, suggesting that a multifactor approach is a useful strategy in the treatment of sepsis [74-80]. Of note, three of these studies described similar populations with a high percentage of end-stage renal disease in the control group being prone for higher mortality [76,77,79,81]. Although attainment of $\mathrm{ScvO}_{2}>70 \%$ has been reported as a prominent factor for survival [82], several studies that used EGDT without this specific target were also able to achieve a survival benefit [83-85]. In summary, as shown by Nguyen and colleagues [86], the use of (modified) EGDT implies early recognition of the critically ill patient and enforces continuous reassessment of treatment. This observation seems to be the greatest gain in the treatment of patients with severe sepsis or septic shock over the past decade.

Earlier studies that enrolled patients admitted to the ICU were unable to show a decrease in mortality after aggressive haemodynamic optimisation [57,69]. In contrast, more recent studies that used modified EGDT protocols were able to show a significant decrease in mortality $[85,87,88]$, suggesting that compliance to dedicated sepsis bundles after the emergency department stage can still be useful.

Low incidences of low $\mathrm{ScvO}_{2}$ values at ICU admission [89] or emergency department presentation [90] do occur together with baseline mortality, however, compared with the original EGDT study $[73,89,90]$. For clinical appreciation of the above-mentioned results, a thorough look into the data is needed. Interestingly, fewer patients were intubated before the first $\mathrm{ScvO}_{2}$ sampling in the EGDT study [73], and this could partially explain the difference of initial $\mathrm{ScvO}_{2}$ values between both studies $[73,89]$ : due to higher $\mathrm{DO}_{2}$ (pre-oxygenation) and lower $\mathrm{VO}_{2}$ (sedation, paralysis; lower work of breathing), $\mathrm{ScvO}_{2}$ may very well improve in response to emergency intubation in the majority of patients [91]. This hypothesis partially explains the differences between populations $[73,89,90]$ and provides another piece in the puzzle on the value of $\mathrm{ScvO}_{2}$ [92]. Nevertheless, applicability of the results of the EGDT trial may be dependent on the geographical setting and the underlying healthcare system $[92,93]$.

Additionally, no difference in outcome was found between a resuscitation protocol based on lactate clearance and a $\mathrm{ScvO}_{2}$-based protocol [94], and $\mathrm{ScvO}_{2}$ optimisation does not always exclude a decrease in lactate levels [95]. Also, the pursuit of $\mathrm{ScvO}_{2}>70 \%$ does not always seem to be the optimal solution. Recent data suggest that patients with initially high $\mathrm{ScvO}_{2}$ values may also have adverse outcomes [12,13], probably due to impaired oxygen utilisation. High $\mathrm{ScvO}_{2}$ values may thus represent an inability of the cells to extract oxygen or microcirculatory shunting in sepsis [96].

Finally, as a reflection of an increased respiratory muscle oxygen extraction ratio, a reduced $\mathrm{ScvO}_{2}$ or $\mathrm{SvO}_{2}$ predicts extubation failure in difficult-to-wean patients $[48,97]$. However, a successful intervention to increase $\mathrm{ScvO}_{2}$ in this context is not yet known. Nevertheless, it is conceivable that in the future $\mathrm{ScvO}_{2}$ will be used as a parameter in weaning protocols for a subset of patients $[97,98]$.

\section{Continuous measurement}

Should continuous measurement be considered when venous saturations are used as a therapeutic goal? It may be argued that changes in venous saturations may occur rapidly, particularly in haemodynamically instable patients, and that discontinuous spot measurements by drawing intermittent blood samples may miss these changes. Accordingly, continuous measurement of $\mathrm{SvO}_{2}$ in septic shock patients revealed a higher frequency of short-term changes in $\mathrm{SvO}_{2}$ in nonsurvivors. Variations in $\mathrm{SvO}_{2}$ could thus be of prognostic importance [99]. However, the lack of therapeutic guidelines and cost-effectiveness issues question the clinical use of continuous measurement of $\mathrm{SvO}_{2}$ in critically ill patients $[5,7,58]$. Continuous measurement in perioperative care allows detection of fluctuations. Low $\mathrm{SvO}_{2}$ values have been associated with increased complications and morbidity, especially in cardiac surgery [100]. The use of $\mathrm{SvO}_{2}$ values $>70 \%$ as a target seems promising in cardiac surgery and during cardiopulmonary resuscitation $[38,43]$.

There are currently two commercially available devices to measure $\mathrm{ScvO}_{2}$ continuously. Continuous $\mathrm{ScvO}_{2}$ measurement as part of treatment protocol has shown to be a valuable strategy in the emergency department $[71,73]$ and in cardiac surgery [101]. Additionally, Reinhart and colleagues concluded that continuous $\mathrm{ScvO}_{2}$ measurement in the ICU setting is potentially reliable [26]. However, continuous and intermittent measurements of $\mathrm{SvO}_{2}$ or $\mathrm{ScvO}_{2}$ have never been compared systematically.

\section{Conclusions}

The ongoing debate on differences between $\mathrm{SvO}_{2}$ and $\mathrm{ScvO}_{2}$ and their interchangeability should focus on welldefined populations. $\mathrm{SvO}_{2}$ and $\mathrm{ScvO}_{2}$ are clinically useful but both variables should be used with knowledge and caution. Evaluating the available evidence in a clinical setting, we conclude that low venous oxygen saturations are an important warning sign for the inadequacy of $\mathrm{DO}_{2}$ 
to meet oxygen demands. Low values may warn the clinician about cardiocirculatory or metabolic impairment and should urge for further diagnostics and appropriate action, whereas normal or high values do not rule out persistent tissue hypoxia. Based on the numerous clues for its usefulness discussed in this article, the use of venous oxygen saturations seems especially useful in the early phase of disease or injury. In clinical practice, venous oxygen saturations should always be used in combination with vital signs and other relevant endpoints.

\section{Abbreviations}

CO, cardiac output; DO, systemic oxygen delivery; EGDT, early goal-directed therapy; $\mathrm{Hb}$, haemoglobin; $\mathrm{SaO}_{2}$, arterial oxygen saturation; $\mathrm{SCVO}_{2}$, central venous oxygen saturation; $\mathrm{SvO}_{2}$, mixed venous oxygen saturation; $\mathrm{VO}_{2^{\prime}}$ systemic oxygen demand.

\section{Competing interests}

The authors declare that they have no competing interests.

\section{Author details}

'Department of Anaesthesiology, University Medical Center Groningen, University of Groningen, Hanzeplein 1, Groningen 9700 RB, the Netherlands. 2Department of Intensive Care Medicine, Gelre Hospital Apeldoorn, Albert Schweitzerlaan 31, Apeldoorn 7300 DS, the Netherlands. ${ }^{3}$ Department of Intensive Care Medicine, Academic Medical Center, Meibergdreef 9, Amsterdam 1105 AZ, the Netherlands. ${ }^{4}$ HERMES Critical Care Group, Schweitzerlaan 31, Apeldoorn 7300 DS, the Netherlands. ${ }^{5}$ Department of Intensive Care Medicine, Medical Center Leeuwarden, Henri Dunantweg 2, Leeuwarden 8901 BR, the Netherlands.

Published: 24 October 2011

\section{References}

1. Rady MY, Rivers EP, Novak RM: Resuscitation of the critically ill in the ED: responses of blood pressure, heart rate, shock index, central venous oxygen saturation, and lactate. Am J Emerg Med 1996, 14:218-225.

2. Wo CC, Shoemaker WC, Appel PL, Bishop MH, Kram HB, Hardin E: Unreliability of bloodpressure and heart rate to evaluate cardiac output in emergency resuscitation and critical illness. Crit Care Med 1993, 21:218-223.

3. Vincent $J$ L, De Backer D: Oxygen uptake/oxygen supply dependency: fact or fiction? Acta Anaesthesio/ Scand Supp/ 1995, 107:229-237.

4. Kandel $G$, Aberman A: A mixed venous oxygen saturation: its role in the assessment of the critically ill patient. Arch Int Med 1983, 143:1400-1402

5. Connors AF Jr, SperoffT, Dawson NV, Thomas C, Harrell Jr FE, Wagner D, Desbiens N, Goldman L, Wu AW, Califf RM, Fulkerson Jr WJ, Vidaillet H, Broste S, Bellamy P, Lynn J, Knaus WA: The effectiveness of right heart catheterization in the initial care of critically ill patients. SUPPORT investigators. JAMA 1996, 276:889-897.

6. Sakr Y, Vincent JL, Reinhart K, Payen D, Wiedermann CJ, Zandstra DF, Sprung $\mathrm{CL}$ : Use of the pulmonary catheter is not associated with worse outcome in the ICU. Chest 2005, 128:2722-2731.

7. Harvey S, Harrison DA, Singer M, Ashcroft J, Jones CM, Elbourne D, Brampton W, Williams D, Young D, Rowan K: Assessment of the clinical effectiveness of pulmonary artery catheters in management of patients in intensive care (PAC-Man): a randomised controlled trial. Lancet 2005, 366:472-477.

8. Fick A: Ueber die Messung des Blutquantums in den Herzventrikeln. Verhandl Physik Med Gesellschafft Wurzburg 1870, 2:16-28.

9. Reinhart $\mathrm{K}$ : Monitoring $\mathrm{O}_{2}$ transport and tissue oxygenation in critically ill patients. In Clinical Aspects of $\mathrm{O}_{2}$ Transport and Tissue Oxygenation. Edited by Reinhart K, Eyrich K. Berlin: Springer; 1989: 195-211.

10. Nelson LD: Continuous venous oximetry in surgical patients. Ann Surg 1986, 203:329-333.

11. Kasnitz P, Druger Gl, Yorra F, Simmons DH: Mixed venous oxygen tension and hyperlactatemia. Survival in severe cardiopulmonary disease. JAMA 1976, 236:570-574

12. Perz S, Uhlig T, Kohl M, Bredle DL, Reinhart K, Bauer M, Kortgen A: Low and 'supranormal' central venous oxygen saturation and markers of tissue hypoxia in cardiac surgery patients: a prospective observational study. Intensive Care Med 2011, 37:52-59.

13. Pope JV, Jones AE, Gaieski DF, Arnold RC, Trzeciak S, Shapiro Nl; EMShockNet: Multicenter study of central venous oxygen saturation $\left(\mathrm{ScvO}_{2}\right)$ as a predictor of mortality in patients with sepsis. Ann Emerg Med 2009, 55:40-46.

14. Varpula M, Karlsson S, Ruokonen E, Pettilä V: Mixed venous oxygen saturation cannot be estimated by central venous oxygen saturation in septic shock. Intensive Care Med 2006, 32:1336-1343.

15. Edwards JD, Mayall RM: Importance of the sampling site for measurement of mixed venous oxygen saturation in shock. Crit Care Med 1998, 26:1356-1360

16. Martin C, Auffrey J, Badetti C, Perrin G, Papazian L, Gouin F: Monitoring of central venous oxygen saturation versus mixed oxygen saturation in critically ill patients. Intensive Care Med 1992, 18:101-104.

17. Chawla LS, Zia H, Gutierrez G, Katz NM, Seneff MG, Shah M: Lack of equivalance between central and mixed venous oxygen saturation. Chest 2004, 126:1891-1896

18. Kopterides P, Bonovas S, Mavrou I, Kostadima E, Zakynthinos E, Armaganidis $A$ : Venous oxygen saturation and lactate gradient from superior vena cava to pulmonary artery in patients with septic shock. Shock 2008; 31:561-567.

19. Ho KM, Harding R, Chamberlain J, Bulsara M: A comparison of central and mixed venous oxygen saturation in circulatory failure. J Cardiothorac VasC Anesth 2010, 24:434-439.

20. van Beest PA, van Ingen J, Boerma EC, Holamn ND, Groen H, Koopmans M, Spronk PE, Kuiper MA: No agreement of mixed venous and central venous saturation in sepsis, independent of sepsis origin. Crit Care 2010, 14:R219.

21. Scheinman MM, Brown MA, Rapaport E: Critical assessment of use of central venous oxygen saturation as a mirror of mixed venous oxygen in severely ill cardiac patients. Circulation 1969, 40:165-172.

22. Sander M, Spies CD, Foer A, Weymann L, Braun J, VolkT, Grubitzsch H, von Heymann C: Agreement of central venous saturation and mixed venous saturation in cardiac surgery paients. Intensive Care Med 2007, 33:1719-1725.

23. Gutierrez G, Comignanni P, Huespe L, Hurtado FJ, Dubin A, Jha V, Arzani Y, Lazzeri S, Sosa L, Riva J, Kohn W, Suarez D, Lacuesta G, Olmos D, Mizdraji C, Ojeda A: Central venous to mixed venous blood oxygen and lactate gradients are associated with outcome in critically ill patients. Intensive Care Med 2008, 34:1662-1668.

24. Reinhart K, Rudolph T, Bredle DL, Hannemann L, Cain SM: Comparison of central-venous to mixed-venous oxygen saturation during changes in oxygen supply/demand. Chest 1989, 95:1216-1221.

25. Dueck MH, Klimek M, Appenrodt S, Weigand C, Boerner U: Trends but not individual values of central venous oxygen saturation agree with mixed venous oxygen saturation during varying hemodynamic conditions. Anesthesiology 2005, 103:249-257.

26. Reinhart K, Kuhn HJ, Hartog C, Bredle DL: Continuous central venous and pulmonary artery oxygen saturation monitoring in the critically ill. Intensive Care Med 2004, 30:1572-1578

27. Lee J, Wright F, Barber R, Stanley L: Central venous oxygen saturation in shock: a study in man. Anesthesiology 1972, 36:472-478.

28. Ladakis C, Myrianthefs P, Karabinis A, Karatzas G, Dosios T, Fildissis G, Gogas J Baltopoulos G: Central venous and mixed venous oxygen saturation in critically ill patients. Respiration 2001, 68:279-285.

29. Tahvanainen J, Meretoja O, Nikki P: Can central venous blood replace mixed venous blood samples? Crit Care Med 1982, 10:758-761.

30. Vaughn S, Puri VK: Cardiac output changes and continuous mixed venous oxygen saturation measurement in the critically ill. Crit Care Med 1988, 16:495-498.

31. Ruokonen E, Takala J, Uusaro A: Effect of vasoactive treatment on the relationship between mixed venous and regional oxygen saturation. Crit Care Med 1991, 19:1365-1369.

32. Mahutte CK, Jaffe MB, Sasse SA, Chen PA, Berry RB, Sassoon CS: Relationship of thermodilution cardiac output to metabolic measurements and mixed venous oxygen saturation. Chest 1993, 104:1236-1242.

33. Perner A, Haase N, Wiis J, White JO, Delany A: Central venous oxygen saturation for the diagnosis of low cardiac output in septic shock patients. Acta Anaesthesio/ Scand 2010, 54:98-102.

34. Kan K, Koeda T, Ichikawa T, Suzuki T, Kaeakami M, Miura S, Nasu M, Ishikawa M, Koh E, Sato M, Suzuki T, Kato M: Relation between mixed venous blood 
oxygen saturation and cardiac pumping function at the acute phase of myocardial infarction. Jpn Circ J 1989, 53:1481-1490.

35. Ander DS, Jaggi M, Rivers E, Rady MY, Levine TB, Levine AB, Masura J, Gryzbowski M: Undected cardiogenic shock in patients with congestive heart failure presenting to the emergency department. Am J Cardio/ 1998 82:888-891

36. Shah S, Ouellette DR: Early goal-directed therapy for sepsis in patients with preexisting left ventricular dysfunction: a retrospective comparison of outcomes based upon protocol adherence. Chest 2010, 138:897A.

37. Dellinger RP, Carlet JM, Masur H, Gerlach H, Calandra T, Cohen J, Gea-Banacloche J, Keh D, Marshall JC, Parker MM, Ramsay G, Zimmerman JL, Vincent JL, Levy MM: Surviving Sepsis Campaign guidelines for management of severe sepsis and septic shock. Crit Care Med 2008, 34:17-60.

38. Rivers EP, Martin GB, Smithline, Rady MY, Schultz CH, Goetting MG, Appleton TJ, Nowak RM: The clinical implications of continuous central venous oxygen saturation during human CPR. Ann Emerg Med 1992, 21:1094-1101.

39. Scalea T, Holman M, Fuortes M, Baron BJ, Phillips TF, Goldstein AS, Sclafani SJA Shaftan GW: Central venous blood oxygen saturation: an early, accurate measurement of volume during hemorrhage. J Trauma 1988, 28:725-732.

40. Scalea TM, Hartnett RW, Duncan AO, Atweh NA, Phillips TF, Sclafani SJA, Fuortes M, Shaftan GW: Central venous oxygen saturation: a useful clinical tool in trauma patients. J Trauma 1990, 30:1539-1543.

41. Di Filippo A, Gonnelli C, Perretta L, Zagli G, Spina R, Chiostri M, Gensini GF, Peris A: Low central venous saturation predicts poor outcome in patients with brain injury after major trauma: a prospective observational study. Scand J Trauma Resusc Emerg Med 2009, 17:17-23.

42. Waller JL, Kaplan JA, Bauman DI, Craver JM: Clinical evaluation of a new fiberoptic catheter oximeter during cardiac surgery. Anesth Analg 1982, 61:676-679

43. Magilligan DJ, Teasdall R, Eisinminger R, Peterson E: Mixed venous oxygen saturation as a predictor of cardiac output in the postoperative cardiac surgical patient. Ann Thor Surg 1987, 44:260-262.

44. Kirkeby-Garstad I, Sellevold OFM, Stenseth R, Skogvoll E, Karevold A: Marked mixed venous oxygen desaturation during early mobilization after coronary artery bypass surgery: no predictive effect of postoperative ejection fraction. Acta Anaesthiol Scand 2004, 49:1241-1247.

45. Trouwborst A, Tenbrinck R, Van Woerkens EC: Bloodgas analysis of mixed venous blood during normoxic acute isovolemic hemodilution in pigs. Anesth Analg 1990, 70:523-529.

46. De la Rocha AG, Edmonds JF, Williams WG, Poirier C, Trusler RN: Importance of mixed venous oxygen saturation in the care of critically ill patients. Can J Surg 1978, 21:227-229.

47. Hines R, Rafferty T: Right ventricular ejection fraction catheter: toy or tool? $J$ Cardiothorac Vasc Anesth 1993, 7:236-240

48. Jubran A, Mathru M, Dries D, Tobin MJ: Continuous recordings of mixed venous oxygen saturation during weaning from mechanical ventilation and the ramifications thereof. Am J Respir Crit Care Med 1998, 158:1763-1769.

49. Cason CL, DeSalvo SK, Ray WT: Changes in oxygen saturation during weaning from short-term ventilator support after coronary bypass graft surgery. Heart Lung 1994, 23:368-375.

50. Armaganidis A, Dhainaut JF: Weaning from artificial respiration: values of continuous monitoring of mixed venous oxygen saturation. Ann Fr Anesth Reanim 1989, 8:708-715.

51. Polonen P, Ruokonen E, Hippelainen M, Pöyhönen M, Takala J: A prospective, randomized study of goal-oriented hemodynamic therapy in cardiac surgical patients. Anesth Analg 2000, 90:1052-1059.

52. Holm J, Håkanson RE, Vánky F, Svedjeholm R: Mixed venous oxygen saturation is a prognostic marker after surgery for aortic stenosis. Acta Aneasthesiol Scand 2010, 54:589-595.

53. Hamilton MA, Cecconi M, Rhodes A: A systemic review and meta-analysis on the use of preemptive hemodynamic intervention to improve postoperative outcomes in moderate and high-risk surgical patients. Anesth Analg 2011, 112:1392-1402.

54. Shoemaker WC, Appel PL, Kram HB, Waxman K, Lee T-S: Prospective trial of supranormal values of survivors as therapeutic goals in high-risk surgical patients. Chest 1988, 94:1176-1186

55. McKinley BA, Kozar RA, Cocanour CS, Valdivia A, Sailors RM, Ware DN, Moore FA: Normal versus supranormal oxygen delivery goals in shock resuscitation: the response is the same. J Trauma 2002, 53:825-832.

56. Velmahos GC, Demetriades D, Shoemaker WC, Chan LS, Tatevossian R, Wo CC,
Vassiliu P, Cornwel EE 3rd, Murray JA, Roth B, Belzberg H, Asensio JA, Berne TV: Endpoints of resuscitation of critically injured patients: normal or supranormal? A prospective randomized trial. Ann Surg 2000, 232:409-418.

57. Hayes MA, Timmins AC, Yau E, Palazzo M, Hinds CJ, Watson D: Elevation of systemic oxygen delivery in the treatment of critically ill patients. NEng/J Med 1994, 330:1717-1722.

58. Kern JW, Shoemaker WC: Meta-analysis of hemodynamic optimization in high-risk patients. Crit Care Med 2002, 30:1686-1692.

59. Jones AE, Brown MD, Trzeciak S, Shapiro NI, Garret JS, Heffner AC, Kline JA: The effect of a quantitative resuscitation strategy on mortality in patients with sepsis: a meta-analysis. Crit Care Med 2008, 36:2734-2739.

60. Boyd O, Grounds RM, Bennet ED: A randomized clinical trial of the effect of deliberate perioperative increase of oxygen delivery on mortality in highrisk surgical patients. JAMA 1993, 270:2699-2707.

61. Rhodes A, Cecconi M, Hamilton M, Poloniecki J, Woods J, Boyd O, Bennett D, Grounds RM: Goal-directed therapy in high-risk surgical patients: a 15-year follow-up study. Intensive Care Med 2010, 36:1327-1332.

62. Wilson J, Woods I, Fawcett J, Whall R, Dibb W, Morris C, McManus E: Reducing the risk of major elective surgery: randomised controlled trial of preoperative optimisation of oxygen delivery. Br Med J 1999, 318:1099-1103.

63. Sandham JD, Hull RD, Brant RF, Knox L, Pineo GF, Doig CJ, Laporta DP, Viner S, Passerini L, Devitt H, Kirby A, Jacka M: A randomized, controlled trial of the use of pulmonary-artery catheters in high-risk surgical patients. NEngl J Med 2003, 348:5-14.

64. De Backer D, Creteur J, Vincent JL: Perioperative optimization and right heart catheterization: what technique in which patient? Crit Care 2003, 7:201-202.

65. Pearse R, Dawson D, Fawcett J, Rhodes A, Grounds RM, Bennett ED: Early goal-directed therapy after major surgery reduces complications and duration of hospital stay. A randomised controlled trial [ISRCTN38797455]. Crit Care 2005, 9:R687-R693

66. Pearse R, Dawson D, Fawcett J, Rhodes A, Grounds RM, Bennett ED: Changes in central venous saturation after major surgery, and association with outcome. Crit Care 2005, 9:R694.

67. Collaborative Study Group on Perioperative $\mathrm{ScvO}_{2}$ Monitoring: Multicentre study on peri- and postoperative central venous oxygen saturation in high-risk surgical patients. Crit Care 2006, 10:R158.

68. Donati A, Loggi S, Preiser JC, Orsetti G, Münch C, Gabbanelli V, Pelaia P, Pietropaoli P: Goal-directed intraoperative therapy reduces morbidity and length of hospital stay in high-risk surgical patients. Chest 2007 132:1817-1824.

69. Gattinoni L, Brazzi L, Pelosi P, Latini R, Tognoni G, Pesenti A, Fumagalli R: A trial of goal-oriented hemodynamic therapy in critically ill patients. NEngl J Med 1995, 333:1025-1032

70. Alía I, Esteban A, Gordo F, Lorente JA, Diaz C, Rodriguez JA, Frutos F: A randomized and controlled trial of the effect of treatment aimed at maximizing oxygen delivery in patients with severe sepsis or septic shock. Chest 1999, 115:453-461.

71. Rady MY, Rivers EP, Martin GB, Smithline H, Appelton T, Nowak RM: Continuous central venous oximetry and shock index in the emergency department: use in the evaluation of clinical shock. Am J Emerg Med 1992, 10:538-541.

72. Task Force of the American College of Critical Care Medicine, Society of Critical Care Medicine: Practice parameters for hemodynamic support in adult patients in sepsis. Crit Care Med 1999, 27:639-660.

73. Rivers E, Nguyen B, Havstad S, Ressler J, Muzzin A, Knoblich B, Tomlanovich M; Early Goal-Directed Therapy Collaborative Group: Early goal-directed therapy in the treatment of severe sepsis and septic shock. NEng/ J Med 2001, 345:1368-1377.

74. Trzeciak S, Dellinger RP, Abate NL, Cowan RM, Stauss M, Kilgannon JH, Zanotti S, Parrillo JE: A 1-year experience with implementing early goal-directed therapy for septic shock in the emergency department. Chest 2006, 129:225-232.

75. Kortgen A, Niederprüm, Bauer M: Implementation of an evidence-based 'standard operating procedure' and outcome in septic shock. Crit Care Med 2006, 34:943-949.

76. Jones AE, Focht A, Horton JM, Kline JA: Prospective external validation of the clinical effectiveness of an emergency department-based early goaldirected therapy protocol for severe sepsis and septic shock. Chest 2007, 132:425-432. 
77. Puskarich MA, Marchick MR, Kline JA, Steuerwald MT, Jones AE: One year mortality of patients treated with an emergency department based early goal directed therapy protocol for severe sepsis and septic shock: a before and after study. Crit Care 2009, 13:R167.

78. Micek ST, Roubinian N, Heuring T, Bode M, Williams J, Harrison C, Murphy T, Prentice D, Ruoff BE, Kollef MH: Before-after study of a standardized hospital order set for the management of septic shock. Crit Care Med 2006, 34:2707-2713.

79. Focht $\mathrm{A}$, Jones $A \mathrm{E}$, Lowe TJ: Early goal-directed therapy: improving mortality and morbidity of sepsis in the emergency department. Jt Comm J Qual Patient Saf 2009, 35:186-191.

80. Shapiro NI, Howell MD, Talmor D, Lahey D, Ngo L, Buras J, Wolfe RE, Weiss JW, Lisbon A: Implementation and outcomes of the Multiple Urgent Sepsis Therapies (MUST) protocol. Crit Care Med 2006, 34:1025-1032

81. Sarnak MJ, Jaber BL: Mortality caused by sepsis in patients with end-stage renal disease compared with the general population. Kidney Int 2000, 58:1758-1764.

82. Castellanos-Ortega A, Suberviola B, Garcia-Astudillo LA, Holanda MS, Ortiz F, Llorca J, Delgado-Rodriguez M: Impact of the Surviving Spesis Campaign protocols on hospital length of stay and mortality in septic shock patients: results of a three-year follow-up quasi-expirimental study. Crit Care Med 2010, 38:1036-1043.

83. Gao F, Melody T, Daniels DF, Giles S, Fox S: The impact of compliance with 6-hour and 24-hour sepsis bundles on hospital mortality in patients with severe sepsis: a prospective observational study. Crit Care 2005 9:R764-R770.

84. Sebat F, Johnson D, Musthafa AA, Watnik M, Moore S, Henry K, Saari M: A multidisciplinary community hospital program for early and rapid resuscitation of shock in nontrauma patients. Chest 2005, 127:1729-1743.

85. Lin SM, Huang CD, Lin HC, Liu CY, Wang CH, Kuo HP: A modified goaldirected protocol improves clinical outcome in intensive care unit patients with septic shock: a randomized controlled trial. Shock 2006, 26:551-557.

86. Nguyen HB, Corbett SW, Steele R, Banta J, Clark RT, Hayes SR, Edwards J, Cho TW, Wittlake WA: Implementation of a bundle of quality indicators for the early management of severe sepsis and septic shock is associated with decreased mortality. Crit Care Med 2007, 35:1105-1112.

87. Moore LJ, Jones SL, Kreiner LA, McKinley B, Sucher JF, Todd SR, Turner KL, Valdivia A, Moore FA: Validation of a screening tool for early identification of sepsis. J Trauma 2009, 66:1539-1547.

88. Zambon M, Ceola M, Almeida-de-Castro R, Gullo A, Vincent JL: Implementation of the Surviving Sepsis Campaign guidelines for severe sepsis and septic shock: we could go faster. J Crit Care 2008, 23:455-460.

89. van Beest PA, Hofstra JJ, Schultz MJ, Boerma EC, Spronk PE, Kuiper MA: The incidence of low venous oxygen saturation on admission in the ICU: a multicenter observational study in the Netherlands. Crit Care 2008, 12:R33.

90. Ho BCH, Bellomo R, McGain F, Jones D, Naka T, Wan L, Braitberg G: The incidence and outcome of septic shock patients in the absence of earlygoal directed therapy. Crit Care 2006, 10:R80.

91. Hernandez G, Peña H, Cornejo R, Rovegno M, Retamal J, Navarro JL, Aranguiz I, Castro R, Bruhn A: Impact of emergency intubation on central venous oxygen saturation in critically ill patients: a multicenter observational study. Crit Care 2009, 13:R63.

92. Stahl W, Radermacher P, Georgieff M, Bracht H: Central venous oxygen saturation and emergency intubation - another piece in the puzzle? Crit Care 2009, 13:172.

93. Bellomo R, Reade MC, Warrillow SJ: The pursuit of high central venous oxygen saturation in sepsis: growing concerns. Crit Care 2008, 12:130.

94. Jones AE, Shapiro NI, Trzeciak S, Arnold RC, Claremont HA, Kline JA; EMShockNet: Lactate clearance vs central venous oxygen saturation as goals of early sepsis therapy. JAMA 2010, 303:739-746.

95. Arnold RC, Shapiro NI, Jones AE, Schorr C, Pope J, Casner E, Parrillo JE, Dellinger RP, Trzeciak S; EMShockNet: Multicenter study of early lactate clearance as a determinant of survival in patients with presumed sepsis. Shock 2009, 32:35-39.

96. Ince C, Sinaasappel M: Microcirculatory oxygenation and shunting in sepsis and shock. Crit Care Med 1999, 27:1369-1377.

97. Teixeira C, Brandao da Silva N, Savi A, Rios Veiira SR, Nasi LA, Friedman G, Pinheiro Oliveira R, Viegas CremoneseR, Tonietto TF, Bressel MAB, Maccari JG, Wickert R, Borges LG: Central venous saturation is a predictor of reintubation in difficult-to-wean patients. Crit Care Med 2010, 38:491-496.

98. Wratney AT: Central venous saturation as a predictor of extubation failure Crit Care Med 2010, 38:708-709.

99. Krafft P, Steltzer H, Hiesmayr M, Klimscha W, Hammerle AF: Mixed venous oxygen saturation in critically ill septic shock patients: the role of defined events. Chest 1993, 103:900-906

100. Pond CG, Blessios G, Bowlin J, McCawley C, Lappas DG: Perioperative evaluation of a new mixed venous oxygen saturation catheter in cardiac surgery patients. J Cardiothorac Vasc Anesth 1992, 6:280-282.

101. Smetkin AA, Kirov MY, Kuzkov W, Lenkin Al, Eremev AV, Slastilin VY, Borodin W, Bjertnaes $L J$ : Single transpulmonary thermodilution and continuous monitoring of central venous oxygen saturation during off-pump coronary surgery. Acta Anaesthesio/ Scand 2009, 53:505-514.

doi:10.1186/cc10351

Cite this article as: van Beest $P$, et al.: Clinical review: use of venous oxygen saturations as a goal - a yet unfinished puzzle. Critical Care 2011, 15:232. 